\title{
The Use of Digital Narratization Technologies in the Training Process for Future Psychologists
}

\author{
Kotlyarova V.V. Rudenko A.M. Shubina M.M.
}

\author{
Institute of Service and Entrepreneurship (branch) of DSTU in the city of Shakhty (ISO\&P (branch) of DSTU in the city \\ of Shakhty), Shakhty, Russia \\ *Corresponding author.Email: Biktoria66@mail.ru
}

\begin{abstract}
In this article, the authors consider the use of digital technologies in education, namely the use of a narrative approach in the educational process of training future psychologists during various types of work experience. As the leading methodological basis of the study, the authors use the cognitive theory of J. Bruner, whose narrative approach is based on the views of the outstanding Russian psychologist L.S. Vygotsky. The authors substantiate that it is advisable to combine the use of narrative technologies with the elements of the practical activity of students. The authors present the criteria and levels for assessing the effectiveness of the formation of professional competencies of future psychologists using narrative technologies in the form of three evaluation sections: assignment assessment (the experimental part of the assignment to practice); participation in the analysis of the experiment; reflective work with the obtained data, based on the model of $\mathrm{B}$. Robin and S. McNeil (ADDIE model).
\end{abstract}

Keywords: education, digital technologies, informatization, narrativization of the educational process

\section{INTRODUCTION}

Mankind is going through a time of cardinal, multilevel, global, transformational changes in its being, the rapid evolution of new technologies, computer networks, electronic media, its worldview. This is the time when the information space has become a new reality, a new way of life in which information has become the most important resource of society. Modern society is undergoing a process of transition to a new social structure, a new way of developing human civilization: global informatization. A network society is being formed, the essential feature of which is continuous training and retraining. The ability to receive information, creatively transform and use it is becoming the most necessary practical skills of a person in the information era. The mentality of the young generation studying in higher education in the last decade has undergone significant socio-psychological and sociocultural changes. Their evidence is not in doubt among teachers and is widely discussed in the professional environment. Modern students are called the digital generation, since accessibility, the way they organize and present information in electronic form are decisive for them. Digital technologies of transformation, storage and transmission of information create a powerful source of knowledge for all participants in the educational process. During the rapid development and change of the realities of global digital society, the almost non-alternative human presence in multiple realities that are constantly being technologically improved and transformed, education should offer new approaches to using digital technologies both in the educational process as a whole and in training.
The authors focus on such technology of the educational process as narrative technologies and their possibilities of application in the training of psychologists.

\section{METHODS}

The purpose of the study is to analyze the implementation of a methodological system for designing digital narratives in the educational process of training future psychologists in the process of passing various types of industrial practice and assessing that increase the level of professional competencies

To achieve the goal of the study, a set of general scientific methods was used, which determined the interaction between each other, and which complemented each other and provided the possibility of a comprehensive study of the subject and object of study. The following methods were used in the complex: analysis of philosophical, pedagogical, psychological, sociological scientific sources to clarify the development of the problem and determine the main categories of research, comparative pedagogical analysis to study foreign experience, design to determine the criteria and develop a model for designing digital narratives.

As the leading methodological basis of our study, we take the cognitive theory of J. Bruner [1], who is the founder of the global transformational and interpretative paradigm in learning, called the "narrative". Note that this narrative approach is based on the views of the outstanding Russian 
psychologist L. Vygotsky [2]. The most famous in the English-language educational space and available on the Internet is the basic training manual for creating digital narratives by S. R. Tolisano "Digital Narrative Technologies for Teachers," which she wrote and posted in 2009 on her personal educational website [3]. Based on her research, we will further propose technology for choosing narratives adapted to Russian conditions.

\section{RESULTS}

The emergence of the global Internet, the development of international economic integration in the direction of the formation of international integration associations and the globalization of the economy have created the prerequisites for the formation of an innovative process at the global level [4], therefore, one of the most important trends in the development of higher education is informatization.

The processes of digitalization and the ever-increasing informatization of society lead to an exponential growth of scientific literature, which in turn greatly actualizes the inclusion of active digital components in the process of training specialists in the person to person profession. Education is one of the leading sectors of modern society. Its essence has undergone a transformation since the beginning of the informatization of society in the $60 \mathrm{~s}$. Dutch scientists S. Marginson and M. Van der Wende in their joint work "Globalization and Higher Education" focus on this [5].

A whole interdisciplinary direction of scientific research and projects is emerging in the world: Digital Humanities. We find the origins of digital narratives in digital humanism, which aims to use computer systems for various humanitarian studies. Digital humanism is an interdisciplinary branch of knowledge that explores the experience of using computer systems in the social humanitarian field, integrates technology, intelligent systems, human sensitivity, contextuality and is aimed at socio-humanitarian research on the use of high-tech services, human-centered systems that ensure continuous social development.

The term "narrative" comes from the Latin word "narrare", which means telling a story. Based on the works of modern foreign and domestic scientists regarding the study of narrative, their approaches to the interpretation of this term, it can be noted that in the traditional sense, a narrative is defined as a text describing a certain sequence of events, that is, as a story, story, description or message. The process of gradual narrativization of humanitarian thought goes back to the second half of the 60s and covers the 70-90s, and in fact, in the 90s of the XX century, it becomes so expressive that it acquires the status of revolutionary changes, which, according to many scientists, at the present stage, they have not only not disappeared, but transformed practically all areas of human cognition and educational disciplines. The quintessence of the "narrative turn" in the social and humanitarian sciences was the assertion that the functioning of various forms of knowledge can be understood only through the study of their narrative, narrative nature.

Since the $80 \mathrm{~s}$ of the twentieth century, a narrative approach has become widespread in foreign educational practices, providing for the activation of verbal methods for interpreting life experience in the form of compiling various legends that involve stimulating the processes of self-knowledge and self-development of a person.

A significant impetus to the study of narrative was the development of the humanities, a new hermeneutic, ontological and historical picture of self-consciousness, which determined the direction of critical and historical theories in the works of H.G. Gadamer, H. White, P. Ricoeur.

In foreign practices of teacher education, narrative learning strategies are quite common, since they are considered as an integral part of the personality-creative development paradigm for pupils and teachers, students and teachers. The problem of digital narratives is devoted to the fundamental work of an international collective [6]. The search for foreign scientists in the use of narratives in education focuses on the following areas: history as a narrative, narrative and professional development, narrative in educational practices, narrative interviews and reflective practice, narrative as a method of data analysis, narratives and methods of qualitative research, critical pedagogy, culture , global education, intercultural education, language education, teaching methods in various disciplines.

In the scientific work "Teacher Stories", M. Jalongo and J. Isenberg argue that narratives create a context that brings people, experience, and time together. Each good story, regardless of the time that it describes, is perceived as one that has just taken place. Moreover, stories also stimulate the preservation of events in memory, their reproduction, and study [7, 28]. Thus, narratives become the tool that educators can use to share professional finds and experiences.

The manual by K. Egan [8] "Learning with the Stories" is of great practical importance because it reveals the use of stories as a method and form of learning. The model developed by K. Egan gained well-deserved fame among the pedagogical community. The author explores the feasibility of introducing narratives into daily learning practices; the conditions under which the use of narratives becomes an effective natural means of communication with students. In the manual, the researcher offers her own model of narrative learning, which is an alternative to traditional.

The leading researcher in the field of the use of narrative in educational processes, the American scientist J. Bruner [1] emphasizes that a person is determined to tell stories, that is, to organize disparate information, organize it into a single whole and share the results with others. If students are given the opportunity to develop and use this natural gift, then they will gradually acquire the necessary communicative competencies, a sense of confidence in their own abilities, which in turn helps the development of intellectual skills. 
In the Russian educational space, interest in narrative practices is manifested in the context of teaching foreign languages (Manyakina N.V., Nadtocheva E.S.) [9], humanitarian disciplines as an auxiliary tool (as an illustration) in the teaching process. Moreover, as notes L.A. Gorokhova, "among the authors-theoreticians and among practicing educators there is no single view on this technology" [10].

Digital narratives are often served in compelling and emotionally filled formats that can be interactive. The concept of "digital narratives" also refers to a wide range of digital stories posted on websites, interactive texts and computer games. At first, this category was used in a general sense in relation to film production, and later it began to be applied in the media space (commercial and social advertising).

At present, narratization is widely recognized as an effective, meaningful, enjoyable, and creative way to enhance teaching and learning [11].

Digital narratives focus on a specific topic and, most importantly and decisively, reflect a certain point of view. The topic of digital narratives covers a fairly wide range: from personal stories, tales to the description of historical events; from the study of life in one's own environment to the search for life in different parts of the universe and almost everything in the world. The digital narrative category includes digital texts, presentations, stories, blogs, video clips, animated films, video blogs, photo collages, social media event descriptions, twitter novels, etc.

Synonymously close to the category of digital narratives is the concept of digital stories, digital stories. In scientific works, the category of digital narratives is more often used, and the concept of digital stories, digital stories are found in educational and methodical and popular science sources, materials.

It should be noted that the simplest digital narrative can even be presented in the form of a PowerPoint presentation, which is quite effective in combining text, video and audio information media.

The advantages of digital narratives are often identified with the ability to choose from a wide array of technical tools those that are convenient for creative expression of the creators of the narrative, and use these tools to provide a new variety of reflections with informational messages. When creating digital narratives, it is important to purposefully use the software, select images, edit videos, make voiceover, add music, create screensavers, manage the personnel flow and transitions between different modalities. In addition, it is possible to implement interactive functions in order to click on an image or text, choose what will happen next, establish the causes of the incident, what is happening, or switch to other content.

\section{DISCUSSION}

Awareness of the significance of narrative as a way of understanding the surrounding reality led to a rethinking of the process of training future psychologists. Modern research in the field of cognitive science shows that a person's understanding of reality is not reproductive, but constructive, which means that information that is perceived by a person is interpreted and reconstructed through the prism of the knowledge, attitudes, aspirations, and intentions that a person has in currently.

Today, the use of digital narratives is implemented in various public centers, educational institutions, libraries, enterprises, both novice users and experienced specialists in the field of information and communication technologies. Digital narratives in various educational content forms are used in all areas of the continuing education system (from kindergartens, primary, secondary and higher schools to postgraduate studies, postgraduate education for adults and people of the third age). And we agree with the point of view of $R$. Clarke that narrativization can promote intellectual interaction for students as beginners of academic writing, and for those who experience problems with academic writing conventions. In this regard, digital narration can complement traditional assessment methods [12].

Digital narratives are becoming an important interactive form of modern communication, common to all and equally common to children and parents, pupils and teachers, teachers and students. The essence of creating digital narratives is to use information and communication technologies for storytelling. There are many terms to describe this practice: digital documentaries, digital narratives, digital essays, electronic memoirs, digital interactive stories. But in general, they all correlate with the idea of combining the art of oral narration with a variety of multimedia, including graphics, audio, video and web publishing.

Let us further consider how the authors of the article use digital narratives in their educational activities. The training of certified psychologists at the Don State Technical University is carried out in the areas of training for bachelors (03.37.01 Psychology) and masters (04.37.01 Psychology). Both bachelors and masters in the process of training undergo practical training, and practical training in the process of training masters takes a fairly large amount of time. The main activity of masters is research and teaching, and the activities of bachelors are practical, research and teaching. The many years of experience of the authors of the article on working with students, future psychologists, suggests that very often, in the presence of original and interesting research results, students can not correctly and interestingly present it. The authors believe that the use of narrative technologies in the learning process will avoid this problem. It is advisable to combine the use of narrative technologies in the training of future psychologists with the elements of practical activity of students, i.e. first of all, in the preparation, execution of assignments and the protection of reports on industrial practice (the practice of obtaining professional skills and experience in professional activities, research work, pedagogical and undergraduate practice).

The practical training of both masters and bachelors involves the use of elements of a psychological experiment, its processing, and presentation of the results. 
From the moment experimental studies in psychology began to be carried out, any psychological research is accompanied by the use of an extensive mathematical apparatus. It is precisely the narrativization of the results of psychological research, a demonstration of both the process of applying psychological techniques and their processing, the combination of video and audio materials that allows not only the student to effectively protect the report on practice but also present it to a wide audience.

The criteria and levels for assessing the effectiveness of the formation of professional competencies of future psychologists using narrative technologies, we propose to present in the form of three evaluation headings: assessment of tasks (implementation of the experimental part of the task to practice); participation in the analysis of the experiment; reflective work with the received data.

In the process of evaluating the effectiveness of the formation of professional competencies, we focus on the work of B. Robin and S. McNeil, who proposed methodological foundations for the introduction of digital narratives in educational practices [13]. These frameworks are structured as an ADDIE model. ADDIE-model is an acronym formed from the words: A - analysis, D - design, D - develop, I - implement, E - evaluate.

Let us characterize and analyze the essence of methodological provisions in the context of the training of future psychologists. In the first analytical phase (A) of training to create digital narratives to the head of practice (leading specialist), it is advisable to analyze the individual characteristics of the students, determine the purpose and objectives of the experimental study that should be implemented; that is, to analyze the educational potential of the digital narrative, taking into account the capabilities of those who will create it.

At the design phase (D) of creating a digital narrative, the student and the leader make a joint decision on how the storyline should be built according to the analysis. At this stage, students create a working diagram of the future digital narrative, which may contain text, drawings, diagrams, tables, diagrams with data from psychological research, instructions regarding sound design, and also process and systematize the relevant information media (photos, videos, text files).

In the development phase (D), the creators of the digital narrative make up the designed product using the appropriate software. In the implementation phase (I), the creators of the digital narrative plan to use it with the greatest efficiency; for this purpose, appropriate software is selected and used to develop additional methodological materials (for example, a program of socio-psychological training). In the evaluation phase (E), the creators of digital narratives evaluate, determine the quality of the created digital product in accordance with the task. At this phase, various types of assessment are used to determine how much the creators of the digital narrative have managed to realize their creative intent. It also analyzes possible options for improving the storyline and additional materials used to create it.

With a narrative approach, an active and objective study of the problem that is solved in the course of practical training is aimed at expanding the scope of awareness and ethical responsibility of the future psychologist, which requires the use of various approaches and models. Any interpretation of events, if it is built professionally and not biased, without the desire to dominate, to impose one's point of view, contributes to a more adequate understanding of mental processes and conditions, expansion of a person's worldview, development of tolerance. The purpose of creating digital narratives and the use of modern technologies in the training of future psychologists are the development of creativity, the search for life meanings, a deeper understanding of the world around, the ability to analyze own experience, constantly learn new things, and express own point of view.

\section{CONCLUSION}

The digitalization of higher education is one of the leading trends in the development of the international educational space.

The peculiarity of psychological information is that it requires the use of various mental strategies, is aimed not only at the socio-psychological impact on the human psyche but also at creating mechanisms for monitoring its results. Experts in the field of personality psychology emphasize that for the development of personality creativity, reinforcement is necessary in the form of an environment with a high degree of uncertainty and multivariance. Unlimited material of this kind is provided by digital narratives in a variety of non-trivial approaches to search activity and ways of presenting the results of psychological research.

A digital narrative is a dynamic means of transmitting informational messages, in which the word, image, and sound are expressed in a joint digital code. The digital narrative can be interpreted as a way of transmitting the rational-logical and sensual-emotional components of an information message using digital technologies, which makes it possible to expand, replenish a number of meanings and shades in the course of interpreting one's own point of view on the event that is being described. The use of narrative technologies in the training of future psychologists is advisable to combine with the elements of practical activity of students in the process of passing various types of their practice. The criteria and levels for assessing the effectiveness of the formation of professional competencies of future psychologists using narrative technologies in the form of three evaluation sections: assignment assessment (the experimental part of the assignment to practice) are presented; participation in the analysis of the experiment; reflective work with the obtained data, based on the model of B. Robin and S. McNeil (ADDIE model).

The results of the studies showed that there are no clear unified rules for creating and presenting a digital narrative. At the same time, the typical stages of the creative process can be distinguished: definition of a theme; narrative storyline development; the use of means to actualize the attention of recipients; definition of ways to interpret one's 
own point of view; scoring and visualization of the narrative; establishing the length of the digital narrative.

\section{REFERENCES}

[1] Dzh. Bruner, Kul'tura obrazovaniya, Dzherom Bruner; per. L.V. Trubitsynoy, A.V. Solov'yeva ; Mosk.vyssh.shk. sots. i ekon.nauk. M.: Prosveshcheniye, 2006. 223s.

[2] Ed. L. S. Moll, Vygotsky and Education: Instructional Implications and Applications of Sociohistorical Psycology, Cambridge University Press, 1992. $439 \mathrm{p}$.

[3] S. Tolisano, How-To-Guide Digital Storytelling Tools for Educators, Langvitches : [blog]. 2009. 108 p. Mode of access: http://langwitches.org/blog/wpcontent/uploads/2009/12/Digital-Storytelling-Guide-bySilvia-Rosenthal-Tolisano.pdf. - Title from the screen.

[4] A.M. Rudenko, V.V. Kotlyarova, Vozdeystviye sredstv massovoy kommunikatsii na sovremennoye obshchestvo, Mediaobrazovaniye. 2017. No. 32. S. 134142 .

[5] S. Marginson, M. Van der Wende, Globalisation and higher education. G.: OECD Press, 200674 p.

[6] H. Koenitz, G.Ferri, M. Haahr, D. Sezen and T. I. Sezen, Interactive digital narrative : history, theory, and practice, New York: Routledge, 2015.

[7] M. R. Jalongo, J. P. Isenberg, Teachers' stories. San Francisco, CA: Jossey-BassPublishers, 1995. 304 p.

[8] K. Egan, Teaching as storytelling. Chicago, IL: The University of ChicagoPress. 1989. 132 p.

[9] N.V. Manyaykina, Ye.S. Nadtocheva Tsifrovoye povestvovaniye: ot teorii k praktike, Pedagogicheskoye obrazovaniye v Rossii. 2015. NO 10 S. 60-64.

[10] L.A. Gorokhova Tekhnologiya Digital Storytelling (tsifrovoye povestvovaniye): sotsial'nyy i obrazovatel'nyy potentsial, Sovremennyye informatsionnyye tekhnologii i IT-obrazovaniye. 2016 No. 4 T. 12 s. 40-48

[11] Sh. Wang, H. Zhan, Enhancing Teaching and Learning with Digital Storytelling, 76 International Journal of Information and Communication Technology Education, 6(2), 76-87, April-June 2010 DOI: $10.4018 /$ jicte. 2010040107
[12] R. Clarke, Digital Narrative and the Humanities http://www.utas.edu.au/_data/assets/pdf_file/0004/167 395/Session2b-LT5-Clarke.pdf

[13] B.R. Robin, S.G. McNeil What educators should know about teaching digital storytelling. In: DigitalEducationReview, 2012,22, 37-51. DOI: https://doi.org/10.1344/der.2012.22.37-51 